\title{
FEATURES OF CALIBRATION OF FREQUENCY COMPARATORS
}

\author{
O.M. Velychko ${ }^{1}$, S.M. Shevkun ${ }^{1}$, M.V. Dobroliubova ${ }^{2}$, O.O. Meshcheriak ${ }^{1}$ \\ ${ }^{1}$ State Enterprise «All-Ukrainian State Research and Production Center for Standardization, Metrology, Certification and Consumer \\ Protection» (SE “Ukrmetrteststandard”), 4, Metrologichna Str., 03143, Kyiv, Ukraine, velychko@ukrcsm.kiev.ua, \\ shevkun@ukrcsm.kiev.ua,omeshcheriak@ukrcsm.kiev.ua \\ ${ }^{2}$ National Technical University of Ukraine "Kyiv Polytechnic Institute named after Igor Sikorsky” (KPI named after Igor Sikorsky), \\ 37, Peremogy Av., 03056, Kyiv Ukraine, m.dobroliubova@ukr.net
}

\begin{abstract}
Modern precision measurements of time and frequency are the most accurate measurements among measurements of other physical quantities. They are impossible without the use of highly stable reference frequency sources (frequency standards) and frequency comparators.

The paper presents the main results of research in the calibration of precision frequency comparators using high-precision frequency standards. The structural scheme and model of measurements, and also features of definition of the budget of the measurement uncertainty at calibration are described.

The influence of the most significant influence values on the accuracy of measurement results is analyzed. The content of quantitative and qualitative indicators of corrections that must be taken into account during calibration to achieve the highest measurement accuracy is revealed. Practical results of researches of instability of the frequency entered by the comparator at zero difference of frequencies of input sinusoidal signals at frequency of $5 \mathrm{MHz}$ from the cesium generator in a frequency bandwidth of $3 \mathrm{~Hz}$ on time intervals of $1 \mathrm{~s}, 10 \mathrm{~s}, 1$ hour, and 1 day are resulted.

Practical results include numerical values and plotted on the main indicators of frequency instability, such as: increase in phase difference between signals, relative frequency difference between signals, root mean square relative frequency deviation, root mean square relative two-sample frequency deviation (Allan deviation), and power spectrum of relative deviations of signal frequency.

Uncertainty budgets were compiled and the results of calibration of the frequency comparator $47-308 \mathrm{~A} / 1$ at the time intervals of measurements of $1 \mathrm{~s}, 10 \mathrm{~s}, 1$ hour, and 1 day are given. The main advantages of calibration of comparators with the minimum difference of input frequencies and the optimal number of measurements at each time interval of measurement are shown.

It is expedient to use the described method by each metrological laboratory which carries out calibration of frequency comparators.
\end{abstract}

Keywords: frequency comparator; frequency measure; calibration; measurement uncertainty; time interval.

\section{Introduction}

Precision time and frequency measurements are the most accurate measurements available to mankind [1]. They are impossible without high-precision and highly stable reference frequency sources, which are frequency and time standards. These standards are high-precision standards and are subject to calibration in all countries of the world. There are different methods and different approaches to their calibration. One of the most common and accurate is the method using frequency comparators implemented on the phase measurement method [2, 3]. Such comparators include: multi-channel phase comparator Microsemi MMS, phase noise and deviation analyzers Allan Microsemi 5115A, 5120A, 5125, frequency comparator VCH-314, phase multi-channel comparator VCH-315, receiver-comparator VCH-320, phase comparator VCH-323, phase multichannel comparator 47-315, frequency comparator 47-308A/1, etc.

Obviously, the frequency comparators themselves, in turn, are also subject to calibration. Despite the relative simplicity and prevalence of calibration of frequency comparators, the issues of modeling measurements and determining the uncertainty budget in calibration, quantitative and qualitative correction factors that must be taken into account during calibration, require additional research and are not covered in the scientific literature. These issues become especially relevant when comparators are part of national standards of time and frequency.

The aim of the research is to practically create a methodology (model) of measurements when calibrating frequency comparators with using of precision frequency standards and to highlight the peculiarities of measurement uncertainty estimation of during this calibration.

The scientific novelty is to develop a methodology (model) of measurements when calibrating frequency comparators using high-precision frequency standards, taking into account all the key components of measurement uncertainty, which ensures the accuracy of the methodology to the relative value of extended uncertainty $2 \cdot 10^{-16}$.

\section{Main part}

Consider the calibration of frequency comparators on the example of a frequency comparator Ч-308A/1.

The measurement scheme for calibration of frequency comparators is shown in Figure 1. 


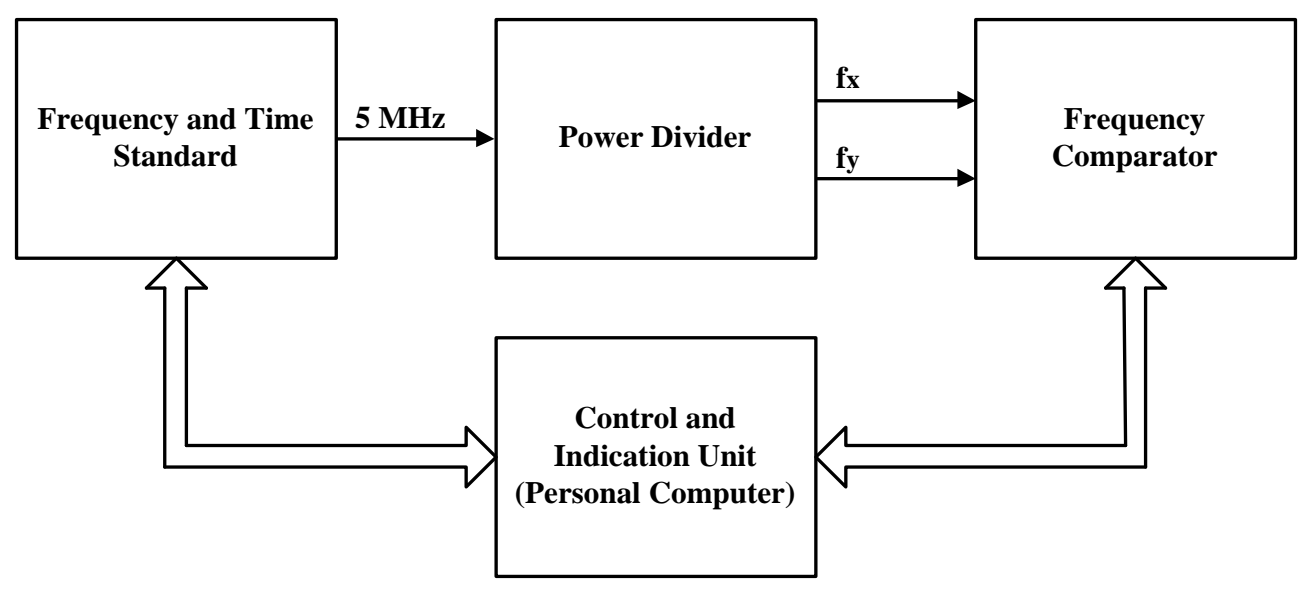

Fig.1. The measurement scheme for calibration of frequency comparators

The scheme includes the following components:

- the frequency and time standard, which is used as a working standard and has the appropriate calibration certificate;

- a power divider, which divides the output signal of the frequency and time standard into two signals and amplifies them to the desired level;

- calibrated frequency comparator;

- a personal computer which, by means of an appropriate interface, performs the functions of a control and indication unit.

Calibration of the frequency comparator is performed at frequencies of 5,10 and $100 \mathrm{MHz}$. The output signal from the reference standard of frequency and time (in this case $5 \mathrm{MHz}$ ) is fed to the power divider. In the power divider, the signal is divided into two signals $f_{x}$ and $f_{y}$, which are amplified to the required level, and then fed to the inputs of the frequency comparator. The use of a power divider helps to increase the accuracy of measurements during calibration.

The $f_{x}$ input is considered to be the input of the reference signal, and the $f_{y}$ input is considered to be the input of the test signal. In this case $f_{y}=f_{x}(1+\delta f)$, where $\delta f=\left(f_{y}-f_{x}\right) / f_{x}$ is the relative frequency difference, which is measured using a frequency comparator.

The frequency comparator implements a phase-time method of frequency measurement, when information about the phase difference of the signals under research is converted into time intervals. These time intervals are measured using a digital time interval meter, which is an integral part of the frequency comparator [4]. Time intervals are automatically converted into the frequency difference of the input signals of the frequency comparator.

\section{Factors affecting the accuracy of frequency comparator measurements}

Studies conducted during the calibration of a significant number of frequency comparators have shown that the most significant influence on the accuracy of frequency measurements is exerted by the following factors:
- frequency fluctuations that occur in the signal conversion circuit in the comparator;

- parasitic phase modulation;

- instability due to the finite number of measurements;

- dependence of the comparator on the rate of temperature change.

Frequency fluctuations that occur in the signal conversion circuit in the comparator cause the instability of frequency difference measurements. This leads to a random error with zero mean (the estimate is unbiased), and in relation to the estimate of frequency instability, this gives a shift of the result towards larger values. The measure of this error is the root-mean-square two-sample relative deviation of the frequency measurement result $\sigma / \sqrt{2}$ (SRD). This value is measured in the "selfmonitoring" mode (checking the instability of the frequency differences introduced by the comparator, with zero frequency difference of the input signals), when the same signal is applied to both inputs of the comparator and the SRD function is calculated. It is allowed to use as a standard and other measures of frequency, for example, rubidium standards with a relative deviation of frequency not more than $5 \cdot 10^{-9}$.

Parasitic phase modulation is present in the frequency comparator in the presence of a difference in the frequencies of the input signals $\Delta f$. It occurs after the frequency conversion and has a frequency $f_{m}$ that is a multiple of the input frequency difference $(m \Delta f)$.

For signals with a frequency of $5 \mathrm{MHz}$, the most significant components are $\Delta f$ and $20 \Delta f(m=1$ and $m=20$ ), for a frequency of $10 \mathrm{MHz}$ are $\Delta f$ and $10 \Delta f$ components, and for a frequency of $100 \mathrm{MHz}$ is a $\Delta f$ component. A characteristic feature of such modulation is the increased scatter of the measured values of the frequency difference and a significant increase in the estimates of frequency instability at some values of the measurement time $\tau$. This error can be calculated based on the amplitude of the phase modulation $A_{m}$ and the frequency response of the calculated function.

The additional frequency instability at the input frequency of $5 \mathrm{MHz}$ should not exceed $2,0 \cdot 10^{-3} \Delta f / f$ 
regardless of the measurement parameters $\Delta f$ and $\tau$. Amplitude of modulation $A_{m}$ (in time units) at an input frequency of $5 \mathrm{MHz}$ for modulation frequencies $\Delta f$ and $20 \Delta f$ does not exceed 10 ps.

The introduced parasitic frequency difference can be calculated by the formula:

$$
\delta f_{m}(t)=\frac{2 A_{m}}{\tau} \sin (\pi m \Delta f \tau) \cdot \sin (2 \pi m \Delta f t+\theta)
$$

where $t$ is the observation time.

Obviously, this value can be reduced by reducing the frequency difference $\Delta f$, ensuring that the condition $\pi m \Delta f \tau<<\pi / 2(\sin (\pi m \Delta f \tau)<<1)$ is met. In this case, expression (1) takes the form

$$
\delta f_{m}(t)=2 A_{m} m \pi \Delta f \cdot \sin (2 \pi m \Delta f t+\theta)
$$

From expression (2) it is possible to determine the maximum value of the allowable difference of frequencies to keep this component of the measurement error within the required limits. To reduce it, the study of frequency instability should be carried out at the minimum possible value of the frequency difference of the input signals $\Delta f$.

Additional instability due to the finite number of measurements $N$ applies only to the random component of the uncertainty (type A) of the frequency difference measurements. The estimation of this uncertainty in the root mean square sense is the relative variance of the results of instability measurement at a given value $N$, which can be represented by an expression with a sufficient accuracy degree $1 / \sqrt{N}$. Therefore, to increase the accuracy of the measurement ten times, it is necessary to ensure that the condition $N>100$ is met at each measurement time interval.

The dependence of the comparator on the rate of change of temperature also leads to a decrease in the accuracy of frequency measurements. The operating temperature range of most frequency comparators is in the range from plus $5^{\circ} \mathrm{C}$ to plus $40^{\circ} \mathrm{C}$. Changes in ambient temperature cause additional phase shifts in the signal conversion path, which can reach $15 \mathrm{ps} /{ }^{\circ} \mathrm{C}$ ). This leads to an additional error in measuring the frequency difference at "long" intervals of measurement time (more than $100 \mathrm{~s})$. Therefore, to reduce the temperature error, it is necessary to eliminate the presence of drafts, fans and ensure the most stable ambient temperature.

As a result of researches it is established that for observance of admissible limits of temperature instability of measurements of a difference of frequencies it is necessary to provide speed of change of ambient temperature no more than $1{ }^{\circ} \mathrm{C} /$ hour.

The calibration of the frequency comparator results in the relative deviation introduced by the comparator when measuring the relative frequency difference between the reference and test signals (hereinafter - the relative deviation), as well as the associated extended uncertainty.

Graphs of the study of the relative deviation of the frequency on the time intervals of averaging 1 hour and $100 \mathrm{~s}$, which were obtained using the interface of the frequency comparator 47-308A/1, are shown in Figures 2 and 3 , respectively.

Large dotted lines show the maximum and minimum values of the relative deviation.

Small dotted line is the value of the standard deviation for the averaging interval of 1 hour.

Dotted line with dots is the average value of the relative deviation.

Figure 4 shows the dependence of SRD on the relative deviation of the frequency from the averaging intervals from $1 \mathrm{~s}$ to 1 day.

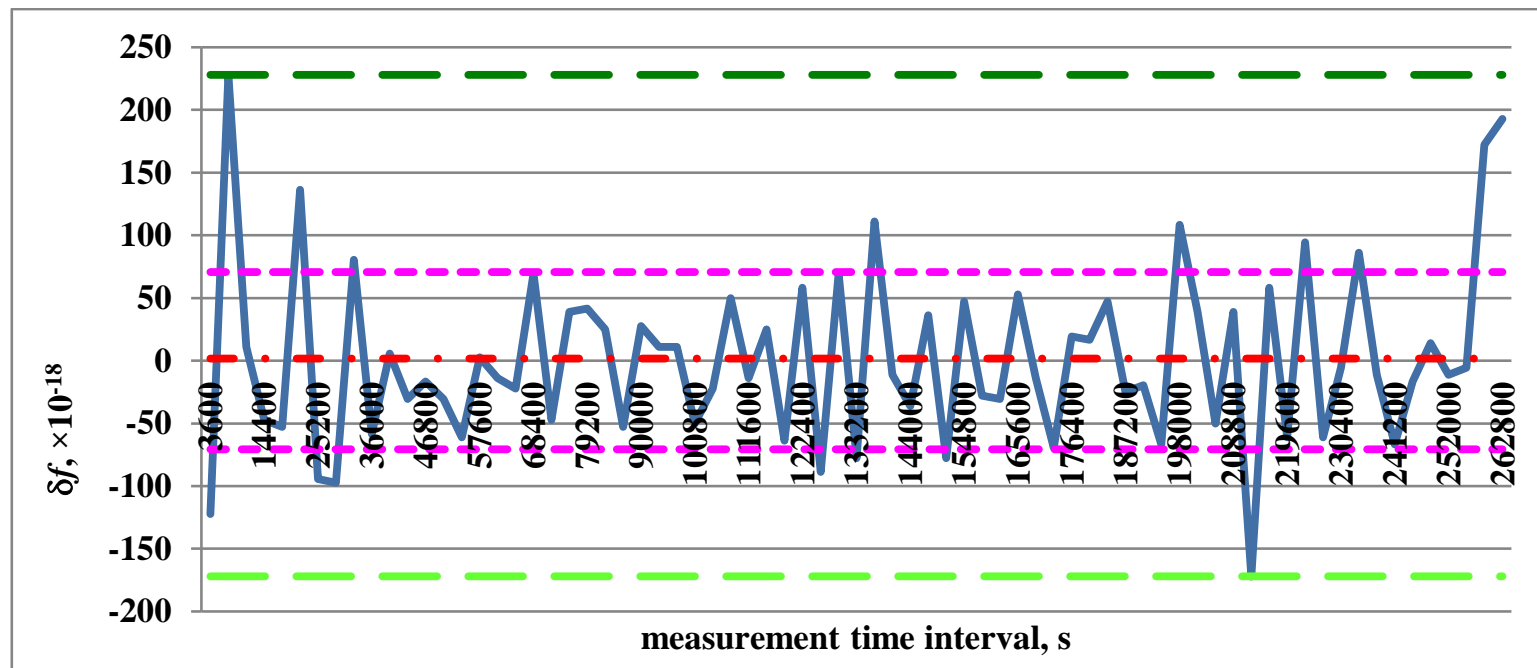

values $-\cdot \cdot$ mean value $\longrightarrow \cdot \max$ value $\longrightarrow \cdot$ min value $--\infty$ standard deviation

Fig.2. The results of the up-to-date value of the typical output frequency for the averaging interval of $100 \mathrm{~s}$ 


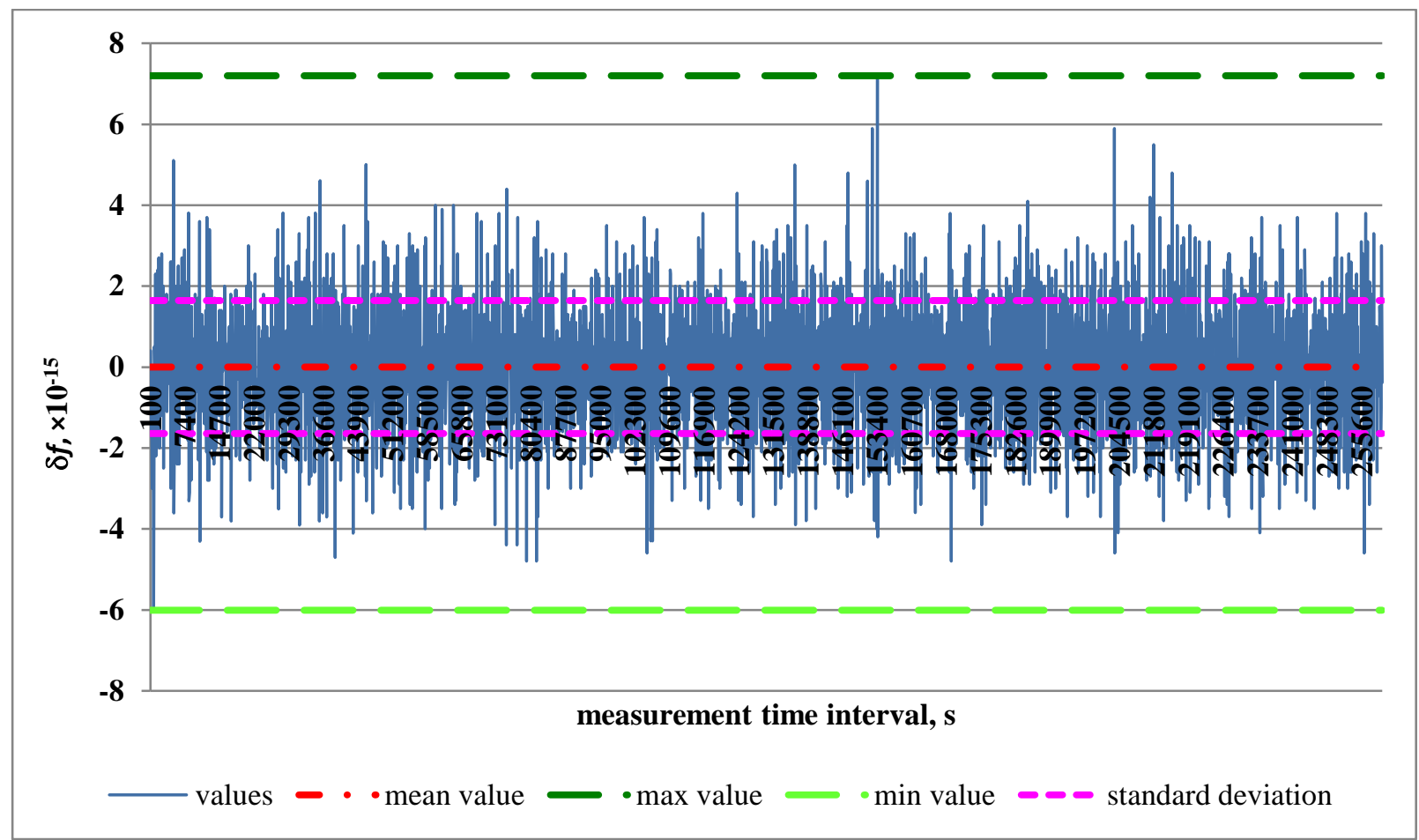

Fig.3. The results of the up-to-date value of the typical output frequency for the averaging interval of 1 hour

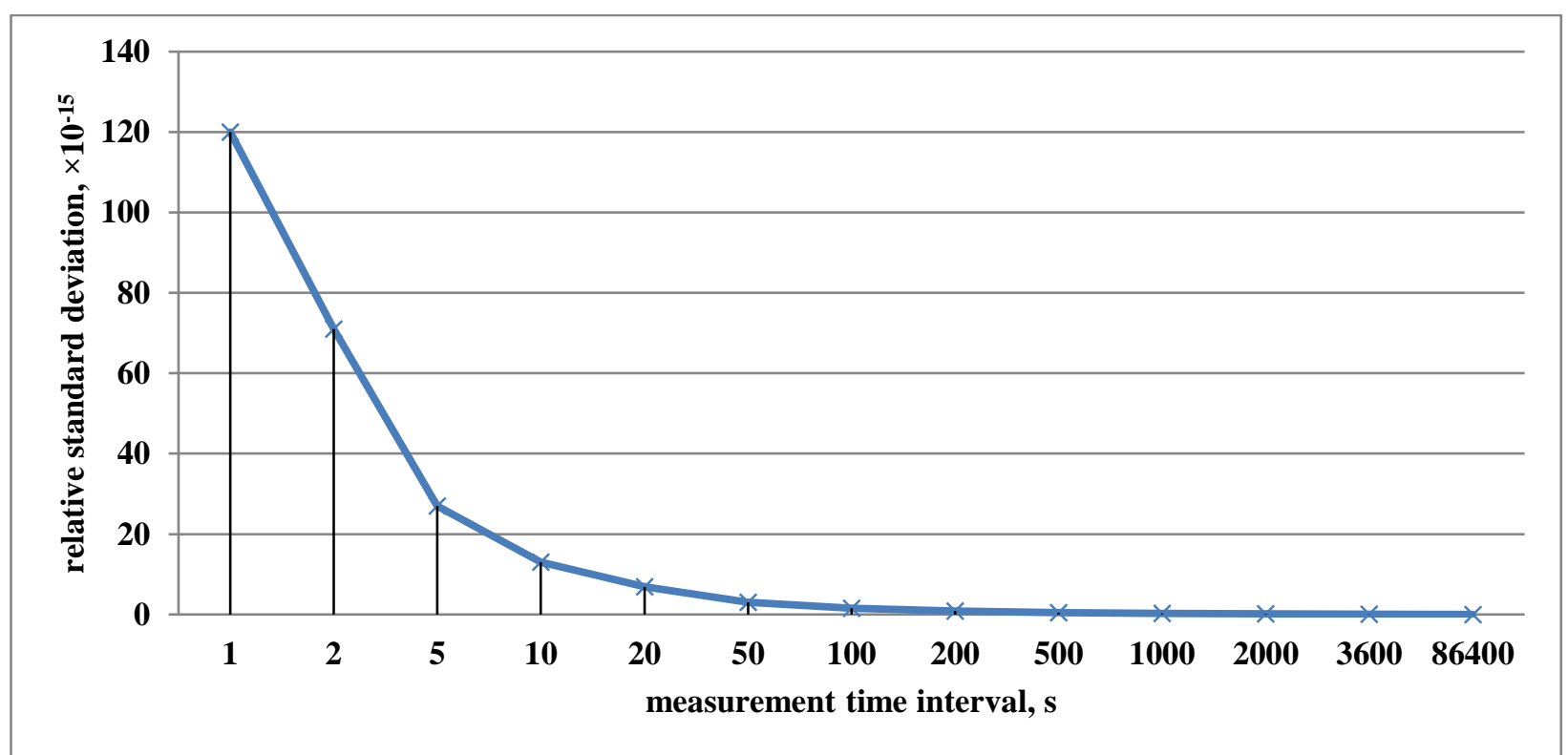

Fig.4. Degree of SRD of the given frequency output and from the intervals averaging from $1 \mathrm{~s}$ to 1 day

It is possible to beat the results in the last few months, but it is always possible to see the results for different intervals of time, however, it is even insignificant $-2,45 \cdot 10^{-19}$. With a large amount of SRD, the relative performance is reasonable for all intervals, there is a great trend of change in its value at larger time intervals.

\section{Measurement model and uncertainty budget}

Based on the measurement scheme, the measurement model when calibrating the frequency comparator has the form:

$$
\delta f_{x}=\overline{\delta f}+\delta f_{X m}+\delta f_{X D}+\delta f_{S T}+\delta f_{X T},
$$

where $\delta f_{x}$ is the relative deviation of the frequency introduced by the comparator, at zero frequency difference of the input sinusoidal signals in the bandwidth at a frequency of $3 \mathrm{~Hz}$;

$\overline{\delta f}$ is the average value of the comparator readings;

$\delta f_{X m}$ is correction due to the presence of parasitic phase modulation in the comparator in the presence of a difference in the frequencies of the input signals $\Delta f$;

$\delta f_{X D}$ is correction for discretization of comparator readings;

$\delta f_{X T}$ is correction due to the influence of the environment on the comparator; 
$\delta f_{S T}$ is correction due to the influence of the environment on the reference standard of time and frequency.

Based on the measurement equation, an example of calculating the uncertainty budget when calibrating the frequency comparator in the measurement time interval of $1 \mathrm{~s}, 10 \mathrm{~s}, 1$ hour and 1 day are given in Tables 1-4, respectively. The calibration result of the frequency comparator is shown in Table 5.

Table 1

Uncertainty budget when calibrating a frequency comparator at a measurement time interval of $1 \mathrm{~s}$

\begin{tabular}{|c|c|c|c|c|c|c|}
\hline $\begin{array}{c}\text { Quantity } \\
X_{i}\end{array}$ & $\begin{array}{c}\text { Estimate } \\
x_{i}\end{array}$ & $\begin{array}{c}\text { Standard } \\
\text { uncertainty } \\
u\left(x_{i}\right)\end{array}$ & $\begin{array}{c}\text { Probability } \\
\text { distribution }\end{array}$ & $\begin{array}{c}\text { Method of } \\
\text { evaluation } \\
(\mathrm{A}, \mathrm{B})\end{array}$ & $\begin{array}{c}\text { Sensitivity } \\
\text { coefficient } \\
c_{i}\end{array}$ & $\begin{array}{c}\text { Uncertainty } \\
\text { contribution } \\
u_{i}(y)\end{array}$ \\
\hline$\overline{\delta f}$ & $2,25 \cdot 10^{-19}$ & $1,29 \cdot 10^{-13}$ & normal & $\mathrm{A}$ & 1 & $1,29 \cdot 10^{-13}$ \\
\hline$\delta f_{X m}$ & $2,74 \cdot 10^{-18}$ & $9,34 \cdot 10^{-17}$ & normal & $\mathrm{B}$ & 1 & $9,34 \cdot 10^{-17}$ \\
\hline$\delta f_{X D}$ & 0 & $5,77 \cdot 10^{-17}$ & rectangular & $\mathrm{B}$ & 1 & $5,77 \cdot 10^{-17}$ \\
\hline$\delta f_{S T}$ & 0 & $5,12 \cdot 10^{-17}$ & normal & $\mathrm{B}$ & 1 & $5,12 \cdot 10^{-17}$ \\
\hline$\delta f_{X T}$ & 0 & $2,29 \cdot 10^{-17}$ & normal & $\mathrm{B}$ & 1 & $2,29 \cdot 10^{-17}$ \\
\hline$\delta f_{x}$ & $2,96 \cdot 10^{-18}$ & & & & & $1,29 \cdot 10^{-13}$ \\
\hline
\end{tabular}

Table 2

Uncertainty budget when calibrating a frequency comparator at a measurement time interval of $10 \mathrm{~s}$

\begin{tabular}{|c|c|c|c|c|c|c|}
\hline $\begin{array}{c}\text { Quantity } \\
X_{i}\end{array}$ & $\begin{array}{c}\text { Estimate } \\
x_{i}\end{array}$ & $\begin{array}{c}\text { Standard } \\
\text { uncertainty } \\
u\left(x_{i}\right)\end{array}$ & $\begin{array}{c}\text { Probability } \\
\text { distribution }\end{array}$ & $\begin{array}{c}\text { Method of } \\
\text { evaluation } \\
(\mathrm{A}, \mathrm{B})\end{array}$ & $\begin{array}{c}\text { Sensitivity } \\
\text { coefficient } \\
c_{i}\end{array}$ & $\begin{array}{c}\text { Uncertainty } \\
\text { contribution } \\
u_{i}(y)\end{array}$ \\
\hline$\overline{\delta f}$ & $2,25 \cdot 10^{-19}$ & $1,30 \cdot 10^{-14}$ & normal & $\mathrm{A}$ & 1 & $1,30 \cdot 10^{-14}$ \\
\hline$\delta f_{X m}$ & $2,74 \cdot 10^{-18}$ & $9,34 \cdot 10^{-17}$ & normal & $\mathrm{B}$ & 1 & $9,34 \cdot 10^{-17}$ \\
\hline$\delta f_{X D}$ & 0 & $5,77 \cdot 10^{-17}$ & rectangular & $\mathrm{B}$ & 1 & $5,77 \cdot 10^{-17}$ \\
\hline$\delta f_{S T}$ & 0 & $5,12 \cdot 10^{-17}$ & normal & $\mathrm{B}$ & 1 & $5,12 \cdot 10^{-17}$ \\
\hline$\delta f_{X T}$ & 0 & $2,29 \cdot 10^{-17}$ & normal & $\mathrm{B}$ & 1 & $2,29 \cdot 10^{-17}$ \\
\hline$\delta f_{x}$ & $2,96 \cdot 10^{-18}$ & & & & & $1,30 \cdot 10^{-14}$ \\
\hline
\end{tabular}

Table 3

Uncertainty budget when calibrating a frequency comparator at a measurement time interval of 1 hour

\begin{tabular}{|c|c|c|c|c|c|c|}
\hline $\begin{array}{c}\text { Quantity } \\
X_{i}\end{array}$ & $\begin{array}{c}\text { Estimate } \\
x_{i}\end{array}$ & $\begin{array}{c}\text { Standard } \\
\text { uncertainty } \\
u\left(x_{i}\right)\end{array}$ & $\begin{array}{c}\text { Probability } \\
\text { distribution }\end{array}$ & $\begin{array}{c}\text { Method of } \\
\text { evaluation } \\
(\mathrm{A}, \mathrm{B})\end{array}$ & $\begin{array}{c}\text { Sensitivity } \\
\text { coefficient } \\
c_{i}\end{array}$ & $\begin{array}{c}\text { Uncertainty } \\
\text { contribution } \\
u_{i}(y)\end{array}$ \\
\hline$\overline{\delta f}$ & $2,25 \cdot 10^{-19}$ & $7,21 \cdot 10^{-17}$ & normal & $\mathrm{A}$ & 1 & $7,21 \cdot 10^{-17}$ \\
\hline$\delta f_{X m}$ & $2,74 \cdot 10^{-18}$ & $9,34 \cdot 10^{-17}$ & normal & $\mathrm{B}$ & 1 & $9,34 \cdot 10^{-17}$ \\
\hline$\delta f_{X D}$ & 0 & $5,77 \cdot 10^{-17}$ & rectangular & $\mathrm{B}$ & 1 & $5,77 \cdot 10^{-17}$ \\
\hline$\delta f_{S T}$ & 0 & $5,12 \cdot 10^{-17}$ & normal & $\mathrm{B}$ & 1 & $5,12 \cdot 10^{-17}$ \\
\hline$\delta f_{X T}$ & 0 & $2,29 \cdot 10^{-17}$ & normal & $\mathrm{B}$ & 1 & $2,29 \cdot 10^{-17}$ \\
\hline$\delta f_{x}$ & $2,96 \cdot 10^{-18}$ & & & & & $1,43 \cdot 10^{-16}$ \\
\hline
\end{tabular}


Table 4

Uncertainty budget when calibrating a frequency comparator at a measurement time interval of 1 day

\begin{tabular}{|c|c|c|c|c|c|c|}
\hline $\begin{array}{c}\text { Quantity } \\
X_{i}\end{array}$ & $\begin{array}{c}\text { Estimate } \\
x_{i}\end{array}$ & $\begin{array}{c}\text { Standard } \\
\text { uncertainty } \\
u\left(x_{i}\right)\end{array}$ & $\begin{array}{c}\text { Probability } \\
\text { distribution }\end{array}$ & $\begin{array}{c}\text { Method of } \\
\text { evaluation } \\
(\mathrm{A}, \mathrm{B})\end{array}$ & $\begin{array}{c}\text { Sensitivity } \\
\text { coefficient } \\
c_{i}\end{array}$ & $\begin{array}{c}\text { Uncertainty } \\
\text { contribution } \\
u_{i}(y)\end{array}$ \\
\hline$\overline{\delta f}$ & $2,25 \cdot 10^{-19}$ & $2,12 \cdot 10^{-18}$ & normal & $\mathrm{A}$ & 1 & $2,12 \cdot 10^{-18}$ \\
\hline$\delta f_{X m}$ & $2,74 \cdot 10^{-18}$ & $9,34 \cdot 10^{-17}$ & normal & $\mathrm{B}$ & 1 & $9,34 \cdot 10^{-17}$ \\
\hline$\delta f_{X D}$ & 0 & $5,77 \cdot 10^{-17}$ & rectangular & $\mathrm{B}$ & 1 & $5,77 \cdot 10^{-17}$ \\
\hline$\delta f_{S T}$ & 0 & $5,12 \cdot 10^{-17}$ & normal & $\mathrm{B}$ & 1 & $5,12 \cdot 10^{-17}$ \\
\hline$\delta f_{X T}$ & 0 & $2,29 \cdot 10^{-17}$ & normal & $\mathrm{B}$ & 1 & $2,29 \cdot 10^{-17}$ \\
\hline$\delta f_{x}$ & $2,96 \cdot 10^{-18}$ & & & & & $1,23 \cdot 10^{-16}$ \\
\hline
\end{tabular}

Table 5

Frequency comparator calibration results

\begin{tabular}{|c|c|c|c|}
\hline No. & $\begin{array}{c}\text { Measurement time } \\
\text { interval, } t\end{array}$ & $\begin{array}{c}\text { Relative deviation of the frequency } \\
\text { entered by the comparator }\end{array}$ & $\begin{array}{c}\text { Extended uncertainty }(U) \text { of the relative } \\
\text { deviation of the frequency introduced by } \\
\text { the comparator }\end{array}$ \\
\hline 1 & $1 \mathrm{~s}$ & & $2,58 \cdot 10^{-13}$ \\
\hline 2 & $10 \mathrm{~s}$ & \multirow{3}{*}{$2,96 \cdot 10^{-18}$} & $2,60 \cdot 10^{-14}$ \\
\hline 3 & 1 hour & & $2,86 \cdot 10^{-16}$ \\
\hline 4 & 1 day and more & & $2,46 \cdot 10^{-16}$ \\
\hline
\end{tabular}

It is worth noting that when compiling the measurement equation and calculating the uncertainty budget, the correction for drift of the frequency reference standard since the last calibration is not taken into account. This is due to the fact that its effect on the measurement result is insignificant.

\section{Conclusions}

The article describes the created methodology (model) of measurements when calibrating frequency comparators using precision frequency standards. Features of estimation of uncertainty of measurements at calibration are covered.

Factors such as frequency fluctuations in the signal conversion circuit in the comparator, parasitic phase modulation, instability due to the finite number of measurements, and the dependence of the comparator on the rate of temperature change have the most significant impact on the accuracy of frequency measurements.

To achieve the highest measurement accuracy when calibrating frequency comparators it is necessary:

- as a standard to use precision frequency measures, for example, rubidium standards with a relative frequency deviation of not more than $5 \cdot 10^{-9}$;

- apply a power divider in which the signal is divided into two channels and their amplification;
- to ensure the rate of change of ambient temperature not more than $1^{\circ} \mathrm{C} /$ hour to reduce the effect of temperature dependence of the frequency comparator;

- to reduce the impact of additional instability due to the finite number of measurements, it is advisable to perform more than 100 measurements at each time interval of averaging.

Calibration of precision frequency measures using a frequency comparator should be performed with the minimum possible difference between the frequencies of the test and reference signals. This will reduce the effect of frequency fluctuations and parasitic phase modulation;

As a result of research it is established that the relative deviation of the frequency difference measurements for different intervals is the same and is very insignificant - about $2,45 \cdot 10^{-19}$. In this case, the SRD relative deviation is different for all measurement intervals and has a clear trend of decreasing its value at larger measurement intervals.

The developed methodology (model) of measurements allows to reach accuracy of calibration of frequency comparators to relative value of the expanded uncertainty $2,00 \cdot 10^{-16}$.

It is expedient to use the described method by each metrological laboratory which carries out calibration of frequency comparators. 


\section{Анотація}

Сучасні прецизійні вимірювання часу та частоти є найбільш точними вимірюваннями серед вимірювань інших фізичних величин. Вони неможливі без використання високостабільних опорних джерел частоти (стандартів частоти) i частотних компараторів.

В статті наведено основні результати досліджень при калібруванні прецизійних частотних компараторів за допомогою високоточних стандартів частоти. Описано структурну схему та модель вимірювань, а також особливості визначення бюджету невизначеності вимірювань при калібруванні.

Проаналізовано вплив найбільш суттєвих впливових величин на точність результатів вимірювань. Розкрито зміст кількісних та якісних показників поправок, які необхідно враховувати під час калібрування для досягнення найвищої точності вимірювань. Наведено практичні результати досліджень нестабільності частоти, що вноситься компаратором при нульовій різниці частот вхідних синусоїдальних сигналів 5 МГц від цезієвого генератора в смузі пропускання частоті 3 Гц на інтервалах часу 1 c, 10 c, 1 год та 1 доба.

Практичні результати включають в себе чисельні значення та побудовані графіки за такими основними показниками нестабільності частоти, як: приріст різниці фаз між сигналами, відносна різниця частот між сигналами, середнє квадратичне відносне відхилення частоти, середнє квадратичне відносне двохвибіркове відхилення частоти (девіація Аллана), спектральна щільність потужності відносних відхилень частоти сигналів.

Складено бюджети невизначеності та наведено результати калібрування частотного компаратора Ч7-308А/1 на інтервалах часу вимірювань 1 c, 10 c, 1 год та 1 доба. Наведено головні переваги калібрування компараторів при мінімальній різниці вхідних частот та оптимальній кількості вимірювань на кожному інтервалі часу вимірювання. Описану методику доцільно використовувати кожною метрологічною лабораторією, яка здійснює калібрування частотних компараторів.

Ключові слова: частотний компаратор; міра частоти; калібрування; невизначеність вимірювань; часовий інтервал.

\section{Аннотация}

Современные прецизионные измерения времени и частоты являются наиболее точными измерениями среди измерений других физических величин. Они невозможны без использования высокостабильных опорных источников частоты (стандартов частоты) и частотных компараторов.

В статье приведены основные результаты исследований при калибровке прецизионных частотных компараторов с помощью высокоточных стандартов частоты. Описаны структурная схема и модель измерений, а также особенности определения бюджета неопределенности измерений при калибровке.

Проанализировано влияние наиболее существенных влияющих величин на точность результатов измерений. Раскрыто содержание количественных и качественных показателей поправок, которые необходимо учитывать при калибровке для достижения наивысшей точности измерений. Приведены практические результаты исследований нестабильности частоты, вносимой компаратором при нулевой разности частот входных синусоидальных сигналов частотой 5 МГц от цезиевого генератора в полосе пропускания по частоте 3 Гц на интервалах времени 1 c, 10 c, 1 час и 1 сутки.

Практические результаты включают в себя численные значения и построенные графики по таким основным показателям нестабильности частоты, как: прирост разности фаз между сигналами, относительная разность частот между сигналами, среднее квадратическое относительное отклонение частоты, среднее квадратическое относительное двухвыборочное отклонение частоты (девиация Аллана), спектральная плотность мощности относительных отклонений частоты сигналов.

Составлены бюджеты неопределенности и приведены результаты калибровки частотного компаратора Ч7-308А/1 на интервалах времени измерений $1 \mathrm{c}, 10 \mathrm{c}, 1$ час и 1 сутки. Приведены основные преимущества калибровки компараторов при минимальной разнице входных частот и оптимальном количестве измерений на каждом интервале времени измерения. Описанную методику целесообразно использовать каждой метрологической лабораторией, осуществляющей калибровку частотных компараторов.

Ключевые слова: частотный компаратор; мера частоты; калибровка; неопределенность измерений; временной интервал.

\section{Список літератури}

1. Карнап Р. Філософські основи фізики: Вступ у філософію науки. М.: Прогрес, 1971. 392 с.

2. Velychko O.M., Shevkun S.M., Meshcheriak O.O., Dobroliubova M.V. Automation of processing of measurement results of parameters of precision frequency measures. Proceedings of the 8-th International Conference on Advanced Optoelectronics and Lasers. Sozopol, Bulgaria. 06-08 September 2019, pp. 657-660. IEEE Catalog Number: CFP19814 USB. ISBN: 978-17281-1813-0.

3. Мещеряк О.О., Величко О.М., Шевкун С.М., Добролюбова М.В. Калібрування прецизійних мір частоти. Системи обробки інформації. 2019. № 1 (156). C. 106-111. DOI: 10.30748/soi.2019.156.14.

4. Компаратор частотный Ч7-308A/1. Руководство по эксплуатации. ЯКУР.411146.011-01РЭ. Нижний Новгород: ЗАО «ВРЕМЯ-Ч», 2014. - 8 с.

5. Компаратор частотный VCH-314. Руководство по эксплуатации. ЯКУР.411146.014РЭ. Нижний Новгород: ЗАО «ВРЕМЯ-Ч», 2014. - 8 с.

\section{References}

1. Karnap R. Philosophical Foundations of Physics: an introduction to the philosophy of science. M.: Progres, 1971. $392 \mathrm{p}$.

2. Velychko O.M., Shevkun S.M., Meshcheriak O.O., Dobroliubova M.V. Automation of processing of measurement results of parameters of precision frequency measures. Proceedings of the 8-th International Conference on Advanced Optoelectronics and Lasers. Sozopol, Bulgaria. 06-08 September 2019, pp. 657-660. IEEE Catalog Number: CFP19814 USB. ISBN: 978-17281-1813-0.

3. Meshcheriak O.O., Velychko O.M., Shevkun S.M., Dobroliubova M.V. Calibration of precision frequency measures. Information processing systems, 2019, no. 1 (156). pp. 106-111 (in Ukrainian). doi: 10.30748/soi.2019.156.14.

4. Frequency comparator प7-308A/1. Manual. User's Manual. ЯКУР.411146.011-01PЭ, ZAO «VREMYa-Ch», Nizhniy Novgorod, 2014, 8 p.

5. Frequency comparator VCH-314. Manual. User's Manual. ЯКУР.411146.014PЭ, ZAO «VREMYa-Ch», Nizhniy Novgorod, 2014, 8 p. 